\title{
The Skin-Resident Immune Network
}

\author{
Szun S. Tay • Ben Roediger • Philip L. Tong • \\ Shweta Tikoo - Wolfgang Weninger
}

Published online: 28 November 2013

(C) The Author(s) 2013. This article is published with open access at Springerlink.com

\begin{abstract}
The skin provides an effective physical and biological barrier against environmental and pathogenic insults whilst ensuring tolerance against commensal microbes. This protection is afforded by the unique anatomy and cellular composition of the skin, particularly the vast network of skin-associated immune cells. These include the longappreciated tissue-resident macrophages, dendritic cells, and mast cells, as well as the more recently described dermal $\gamma \delta \mathrm{T}$ cells and innate lymphoid cells. Collectively, these cells orchestrate the defense against a wide range of pathogens and environmental challenges, but also perform a number of homeostatic functions. Here, we review recent developments in our understanding of the various roles that leukocyte subsets play in cutaneous immunobiology, and introduce the newer members of the skin immune system. Implications for human disease are discussed.
\end{abstract}

Keywords Innate immune system $\cdot$ Langerhans cells $\cdot \gamma \delta \mathrm{T}$ cells $\cdot$ Innate lymphoid cells $\cdot$ Dendritic cells $\cdot$ Macrophages · Mast cells

\section{Introduction}

The skin is a unique organ that serves as an interface between the host and the environment, providing a mechanical and biological barrier against chemical, physical and pathogenic

Szun S. Tay and Ben Roediger contributed equally to the work.

S. S. Tay $\cdot$ B. Roediger $\cdot$ P. L. Tong $\cdot$ S. Tikoo $\cdot$ W. Weninger $(\bowtie)$

Centenary Institute, Locked Bag 6, Newtown, NSW 2042, Australia

e-mail: w.weninger@centenary.org.au

P. L. Tong $\cdot$ W. Weninger

Discipline of Dermatology, University of Sydney,

Sydney 2006, NSW, Australia

P. L. Tong $\cdot \mathrm{W}$. Weninger

Department of Dermatology, Royal Prince Alfred Hospital,

Camperdown 2050, NSW, Australia insults. Anatomically, the skin comprises two distinct compartments: the epidermis, an avascular layer mainly composed of keratinocytes, and the dermis, a fibroblast-rich network of collagen and elastin fibers that provides the skin with strength and elasticity. The dermis also contains capillary and lymphatic vessels, which serve as the entry and exit portals for immune cells. Additional skin appendages such as hair follicles, sebaceous glands and sweat glands, as well as nerve endings are also found in the dermis [1]. The skin is home to a number of immune populations that reside in both the epidermis and dermis. These cells ensure protection against pathogens whilst maintaining tolerance to innocuous antigens, but also contribute to the pathology of a number of inflammatory skin diseases. This immune network is comprised principally of tissue-resident phagocytes, antigen-presenting cells, mast cells and $\mathrm{T}$ lymphocytes, as well as innate lymphoid cells (Fig. 1). Individually, these leukocyte subpopulations perform specialized functions that collectively afford the host its ability to respond to a variety of environmental challenges. In recent years, our understanding of skin immunology has been transformed, with many new insights into both the ontogeny and function of most of the skin-resident immune cells. These developments include the discovery of two hitherto unknown leukocyte populations, the dermal $\gamma \delta$ T cells and group 2 innate lymphoid cells. Here, we review the recent advances in our understanding of the functional diversity of the different immune cell subsets and their role in the cutaneous immune response.

\section{The Skin-Resident Innate Immune Cells}

Macrophages

Macrophages represent a key sentinel population for invading pathogens and tissue damage. These cells also perform developmental and homeostatic functions [2]. Much of our understanding of their roles in vivo has derived from studying macrophage-deficient mice, which include mice lacking the 
Fig. 1 Schematic of skinresident immune cells. DETC dendritic epidermal $\mathrm{T}$ cells; $D C$ dendritic cells; ILC2 group 2 innate lymphoid cells; $L C$ Langerhans cells

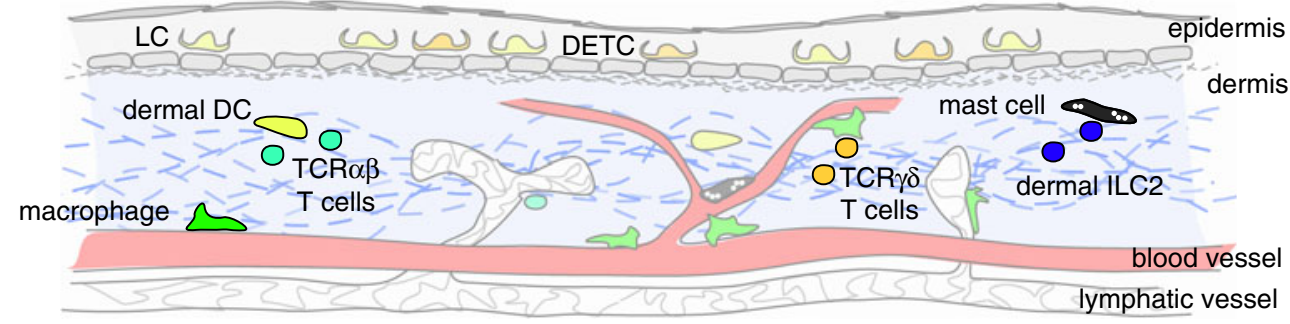

cytokine colony-stimulating factor-1 (CSF-1) or its receptor [3-5]. These animals exhibit a number of developmental and metabolic deficiencies, including defects in iron and erythrocyte homeostasis [6]. Dysregulation or inappropriate activation of macrophages can lead to proinflammatory conditions, and macrophages have been implicated in a number of inflammatory diseases such as atherosclerosis, type 2 diabetes, and cancer [7].

Macrophages comprise a remarkably diverse and heterogeneous population that is found in most tissues, including the skin [8]. During steady-state conditions, macrophages are the most abundant haematopoietic population in the skin $[9,10]$, which likely underscores their importance in maintaining skin integrity and function. They are also important in wound healing, and their critical role in promoting wound closure and tissue repair has been confirmed using recently developed, inducible macrophage-depleter mice [11, 12, 13•]. Macrophages are equipped with a vast array of genetically encoded cell surface and intracellular molecules called 'pattern recognition receptors', which detect both damage-associated and pathogen-associated motifs [14]. Depending upon the nature of the stimulus (e.g., sterile damage or infection), they can produce a variety of proinflammatory cytokines and chemokines that attract specific immune cell subpopulations from the circulation to the site of injury or pathogen invasion [15]. In the later stages of repair, they are able to switch to a growth-promoting [16] and less inflammatory phenotype $[17,18]$, and begin to actively phagocytose apoptotic cells, including apoptotic neutrophils [19], thereby promoting the resolution of inflammation. This remarkable ability to acquire a spectrum of functional phenotypes depending on stimuli allows macrophages to coordinate a myriad of contextappropriate responses to environmental challenges.

A number of transgenic macrophage reporter mice have proven particularly useful for studying macrophage biology [20], and have enabled direct visualization of macrophagepathogen interactions in vivo by both conventional and intravital multiphoton microscopy [21]. Similarly, transgenic mice developed for lineage-tracing experiments have also transformed our understanding of macrophage development. Broadly speaking, macrophages may be tissue-resident or may develop from circulating progenitors in the blood. Developmentally, it was long believed that macrophages derived from circulating monocytes [22], and while that likely holds true for macrophages that arise following inflammation, the origin of tissue-resident macrophages differs markedly.
Rather, most of the tissue-resident macrophages in the skin, spleen, pancreas, liver, brain and lung are, in fact, established prenatally, and arise from the yolk-sac or fetal-liver progenitors $[23,24 \bullet, 25 \bullet \bullet, 26]$. Under some experimental conditions, tissue-resident macrophages appear to be capable of selfrenewing without the need for resupply from the blood [27], although the relative long-term contributions of circulating precursors versus self-renewing populations following inflammation is still under debate [28, 29].

Another layer of complexity lies in the pronounced phenotypic and functional diversity of macrophage subsets. Despite their developmental similarities, the function of macrophages in different organs varies. Red pulp macrophages, for example, are responsible for red blood cell clearance [30], while the microglia in the brain are important for neuronal function [31]. Unsurprisingly, there is wide variation in the receptor usage of macrophages from different tissues [32]. Even within the same organ, there appears to be subset specialization within different microanatomical niches. For instance, macrophages in the different zones of the spleen perform different functions. Marginal zone macrophages are important for trapping blood-borne antigens, whereas red pulp macrophages perform scavenger functions [33].

Within the skin, macrophages have long been thought to be a homogeneous group, primarily serving as a first line of defense against potentially invading pathogens. However, it is likely that skin-resident macrophages are more heterogeneous than previously appreciated. Certainly, macrophages within the skin exhibit a diverse distribution anatomically, where they may be associated with blood vessels (perivascular or "adventitial" macrophages), lymphatic vessels, or may reside in the intervascular space $[34,35]$. It is conceivable then, that perivascular macrophages might be particularly well-suited for regulating leukocyte extravasation, based on their proximity to blood vessels. Similarly, perivascular macrophages may also play a role in regulating local iron homeostasis [36], while those associated with lymphatic vessels may be more important during lymphangiogenesis [35]. Whether strict partitioning of macrophage functions exists within the skin, or if their multiple functions are achieved by functional plasticity remains unclear. Further studies are required to decipher the precise role of specific cutaneous macrophage subsets in cutaneous homeostasis and disease, including wound healing, infections, and skin tumors. 


\section{Dendritic Cells}

Dendritic cells (DCs) represent a subpopulation of antigenpresenting cells that are largely defined by their capacity to present antigens to naïve $T$ cells, for both the generation of immunity against invading pathogens, as well as tolerance to self-antigens and commensal bacteria [37]. With regard to skin DCs, this function requires the capability to migrate via the lymphatics to skin-draining lymph nodes (LNs), where they initiate and shape the downstream adaptive immune response. DC migration to the LNs requires engagement of the chemokine receptor CCR7, expressed by the DC, with one of its two ligands, CCL19 and CCL21, which are in turn expressed by lymphatic endothelial cells [38]. DC migration from the skin may be triggered by a range of noxious and inflammatory stimuli, but also occurs constitutively during steady-state conditions [39, 40]. Skin DCs can be divided into two major populations: Langerhans cells (LC), which reside in the epidermis, and dermal dendritic cells, which reside in the dermis. Although both populations capture and process antigens within the skin and migrate to draining LNs [41, 42], the origins, developmental requirements and behavior of these two populations are quite distinct, as are their functions.

\section{Langerhans Cells}

Langerhans cells (LC) reside in the basal and suprabasal epidermis, where they form a network between keratinocytes. Intravital experiments have shown that LCs remain sessile during steady-state conditions, but that their dendrites extend between keratinocytes in a repetitive fashion [43-45], which may enable the sampling of antigens $[46,47]$. While it is wellaccepted that LCs capture antigens and migrate to skindraining LNs during both steady-state conditions and following inflammation [40], what instruction they provide to naïve $\mathrm{T}$ cells is still hotly debated, with evidence that they can both suppress and initiate skin immune responses [48, 49].

Developmentally, LCs have more in common with macrophages than dermal dendritic cells. LCs develop from a primitive macrophage population during embryogenesis, which can be yolk-sac or fetal liver-derived [25••], and in the absence of inflammation maintain their numbers within the epidermis throughout life by in situ proliferation [41, 50, 51]. This capacity for local self-renewal renders LCs radio-resistant, and the vast majority of LCs do not get replaced by donor bone marrow-derived progenitors following irradiation and stem cell transplantation, a finding that is true of both mice and humans $[52,53,54 \bullet]$. LC development requires IL-34 signaling through the CSF-1 receptor $[55 \bullet \bullet, 56 \bullet \cdot$, and LC homeostasis is maintained by TGF- $\beta$ [57], which is produced by both keratinocytes (paracrine) and LCs themselves (autocrine). During steady-state conditions, a small percentage of LCs constitutively emigrates to the skin-draining LNs [40], but this loss is readily maintained by local proliferation of the remaining LC pool [58]. However, following relatively severe inflammation, for example that induced by ultraviolet irradiation or herpes simplex virus infection, increased numbers of LCs migrate to the LNs $[41,51,59]$ (estimated to be approximately $10-20 \%$ of the total pool; B. Roediger unpublished observations). More significantly, if the epidermal niche becomes sufficiently perturbed, LC homeostasis is compromised and requires replenishment from bone marrow-derived monocytes. These monocytes enter the skin in response to inflammatory chemokines, and follow a chemotactic gradient from the base of the hair follicle to the upper epidermis where they differentiate into LCs [60]. It is currently unclear whether there are functional differences between fetal-origin LCs compared to these monocyte-derived LCs. Although the original study suggested that monocyte-derived LCs could proliferate and maintain themselves in situ [51], a recent study suggests that, following the resolution of inflammation, these cells are ultimately out-competed by those of fetal-origin [61].

Despite being discovered over 100 years ago, the exact immunological role of LCs remains controversial [48, 49]. Early studies suggested that LCs were potent stimulators of T cells, but this was based largely on in vitro experiments, and has been challenged by a number of in vivo studies. The identification of Langerin as a LC-specific marker [62] led to models for specific LC depletion [63-65]. However, these models provided inconsistent data regarding their role in adaptive immune responses, with positive, negative and redundant contributions of LCs to contact hypersensitivity responses being reported [66]. The use of langerin-eGFP reporter mice led directly to the discovery of Langerin ${ }^{+}$dermal dendritic cells, which further confounded interpretations of the LC-depletion models [63-65]. More recently, we and others have exploited the radio-resistance of LCs to exclude the confounding contributions of dermal dendritic cells to naïve T cell responses [39, 67]. Remarkably, LCs were committed to initiating the tolerance of naïve T cells, regardless of the inflammatory stimulus [67]. An immunosuppressive role for LCs in vivo has also been described in other models [68-71], underscoring the difference between the stimulatory behavior of LC in vitro and their suppressive capabilities in vivo. Presumably due to this discrepancy, the murine results have not been confirmed in human studies, which are performed mostly in vitro [72-75].

\section{Dermal Dendritic Cells}

Dermal dendritic cells (DDCs), in contrast to LCs, are a more heterogenous population that relies upon continuous resupply from bone marrow-derived progenitors. In both mice and men, the dermis contains multiple DDC subsets, although the functional specialization of each subset remains largely unknown. In mice, the majority of DDCs express CD11b but not CD103 
$\left(\mathrm{CD} 11 \mathrm{~b}^{\mathrm{hi}} \mathrm{CD} 103^{-}\right)$, but there are also $\mathrm{CD} 11 \mathrm{~b}^{\mathrm{lo}} \mathrm{CD} 103^{+}$Langerin $^{+}$ and $\mathrm{CD} 11 \mathrm{~b}^{-} \mathrm{CD} 103^{-}$subsets $[63-65,76,77]$. In contrast to the sessile LCs, DDCs are highly mobile and continuously migrate throughout the dermis, presumably as part of their immunesurveillance role [44]. During inflammation, DDCs are mobilized rapidly from the skin and arrive in draining LNs within 48 hours, preceding the arrival of LCs, which peak at day 4 [43, 77]. Thus, DDCs are likely to be responsible for shaping the initial $\mathrm{T}$ cell response to skin pathogens.

In addition to their potential to initiate pathogen-specific immune responses $[44,59,78]$, skin DDCs are also detectable within cutaneous LNs during steady-state conditions, suggesting that they are important for maintaining tolerance to skin antigens [39]. They have also been implicated in regulation of the immune response to skin damage [79]. It appears that functional specialization amongst the different DDC subsets enables them to fulfill a variety of diverse requirements. The best example is that of $\mathrm{CD} 11 \mathrm{~b}^{\mathrm{lo}} \mathrm{CD} 103^{+}$Langerin ${ }^{+} \mathrm{DDCs}$, which are highly efficient at cross-presenting antigens to naïve $\mathrm{CD}^{+} \mathrm{T}$ cells compared to the other DDC subsets $[76,80]$, and likely promote Th1-type immune responses [78]. In contrast, a $\mathrm{CD}_{0} 01 \mathrm{~b}^{+}$DDC, distinct from Langerin ${ }^{+}$DDCs, was recently shown to be important for the generation of Th2 responses $[81,82]$. Of note, equivalent subpopulations have been described in human skin, suggesting that many of these functions may be conserved between mice and humans [75, 83]. Indeed, a CD $141^{\text {hi }} \mathrm{DC}$ population has recently been identified in the dermis that shows both transcriptional and functional equivalence to $\mathrm{CD} 103^{+}$DDC [84••], which may have implications for future vaccine design.

\section{Mast Cells}

Mast cells are especially abundant at host-environmental interfaces, including the skin, where they are found in close proximity to the blood vessels in the dermis. Skin mast cells are best known as critical effectors of $\mathrm{Th} 2$ immune responses, including allergic inflammatory diseases, in which environmental allergens trigger their release of pre-formed inflammatory molecules such as histamine, a potent vasodilator [85]. This process is generally mediated via the cross-linking of high-affinity IgE-receptors ( $\mathrm{Fc} \varepsilon \mathrm{RI}$ ) on the mast cell surface by IgE-bound allergens, which in turn promotes tissue inflammation such as urticaria and angioedema. In addition to their role as Th2 effectors, it has been proposed that mast cells participate in pathogen defense, contact hypersensitivity responses, and wound healing, during which they perform both pro- and anti-inflammatory functions [86]. Indeed, the dual pro- and anti-inflammatory properties of mast cells have confounded our understanding of their role in numerous inflammatory conditions, including allergic diseases such as atopic dermatitis. More controversially, mast cells have been implicated in the pathogenesis of a number of autoimmune disease models [87].

Developmentally, mast cells require signaling from the stem cell factor through the Kit receptor for their survival and development, such that mice with defects in Kit signaling and/or expression also lack mast cells. This deficiency can be restored following intradermal injection of in vitro-generated mast cells, which has formed the basis for elucidation of mast cell function in vivo [86, 88]. Studies using these 'knock-in' models have implicated mast cells in protection against bacteria, parasites, and viruses in the skin [89-91].

Nevertheless, studies using Kit-deficient mice must be interpreted in the context of the additional cellular defects exhibited by these animals, since the Kit signaling pathway is also important for hematopoietic stem and progenitor cell, red blood cell and neutrophil development [92-94]. To overcome these shortcomings, mast cell researchers have more recently developed Kit-independent mast cell depleter models, which are currently being used to re-address the role of mast cells in different settings. To date, these studies have confirmed the requirement for mast cells in both the sensitization and effector phases of cutaneous hypersensitivity responses [95] and allergic inflammation [96•], but have questioned their role in autoimmunity $[95,97]$. These mice have also been used to demonstrate the contribution of mast cells to pathology in a murine model of atopic dermatitis [98•], which was consistent with the efficacy of anti-IgE therapy in treating patients with severe atopic dermatitis $[99,100]$.

Mast cells can also be studied by multiphoton microscopy, and it was recently shown that skin mast cells extended cellular processes across vessel walls in vivo in order to acquire IgE from the circulation [101]. We have also used multiphoton microscopy to visualize skin-resident mast cells in situ, where we observed them interacting with group 2 innate lymphoid cells in vivo ([102••]; discussed below).

\section{$\gamma \delta$ T Cell Receptor-Expressing Cells ( $\gamma \delta$ T cells)}

\section{Dendritic Epidermal T Cells}

In addition to being the home of $\mathrm{LCs}$, the murine epidermis is also home to a population of $\mathrm{T}$ cells that have been termed dendritic epidermal T cells (DETC), based on their location and morphology [103]. DETCs are $\gamma \delta \mathrm{T}$ cells that express the canonical $\mathrm{V} \gamma 5 / \mathrm{V} \delta 1 \mathrm{~T}$ cell receptor (nomenclature: [104]). They have no human equivalents but are included in this review to provide context to the recently characterized population of dermal $\gamma \delta \mathrm{T}$ cells that can be found in both mice and humans.

DETCs form tight associations with E-cadherin expressed on keratinocytes [105], and this contributes to their dendritic morphology. Similar to LC, they remain largely immobile, as observed by intravital microscopy [106•]. The ligand for the DETC TCR remains unknown but appears to be constitutively 
expressed by keratinocytes [107]. DETCs require both IL-7 and IL-15 for their maintenance in the skin [106•, 108-110], where they appear to be important for epidermal homeostasis and repair [111]. However, much of our understanding of DETC function, particularly in vivo, has derived from the use of $\mathrm{TCR} \delta^{-/}$mice, which has been predicated upon the assumption that these cells represented the sole $\gamma \delta \mathrm{T}$ cell population within the skin. The recent discovery of an additional population of skin-resident $\gamma \delta \mathrm{T}$ cells, namely the dermal $\gamma \delta \mathrm{T}$ cells, necessitates a revision of these studies. For instance, while the increased keratinocyte apoptosis and delayed wound healing observed in $\mathrm{TCR} \delta^{--}$mice is consistent with the role for DETCs in the epidermis [111-114], the impaired leukocyte recruitment during skin infection with Staphylococcus aureus may be attributed to functions shared by dermal $\gamma \delta \mathrm{T}$ cells, in particular IL-17 production [115].

\section{Dermal $\gamma \delta$ T Cells}

Despite the long-held view that DETCs were the sole $\gamma \delta$ T cell population within the mouse skin, previous studies had indicated the presence of an additional skin-resident population of $\gamma \delta \mathrm{T}$ cells that do not express $\mathrm{V} \gamma 5$ [116, 117]. In transgenic mice engineered to overexpress IL-7 from keratinocytes, spontaneously occurring skin lesions were found to comprise predominantly $\mathrm{V} \gamma 5^{-} \gamma \delta \mathrm{T}$ cells, both within the dermis and epidermis, with only a few DETC. These $\gamma \delta \mathrm{T}$ cells could be elicited from IL-7-stimulated skin organ culture, suggesting they were normally skin-resident. More recently, we and others have extensively characterized this dermal $\gamma \delta \mathrm{T}$ cell subset $[106 \bullet, 118,119]$, confirming they are indeed a dermalresident population that is both phenotypically and functionally distinct from DETCs.

Dermal $\gamma \delta$ T cells constitute $50 \%$ of the total dermal T cell population in mice, 30-50\% of which express the V $\gamma 4$ TCR. They are round or amoeboid in morphology, and a significant proportion are migratory [106•], albeit with slower kinetics than TCR $\alpha \beta$ T cells [120]. Unlike DETCs, dermal $\gamma \delta$ T cells require IL-7 but not IL-15 for their development, and form a long-lived population in the skin that is capable of selfrenewal $[106 \bullet, 121]$. Dermal $\gamma \delta \mathrm{T}$ cells constitutively express IL-23 receptor, CCR6, and ROR $\gamma \mathrm{t}$ molecules associated with Th17 cells [122]. Indeed, they are able to produce IL-17A in response to stimulation by IL- $1 \beta$ and IL-23 or selected tolllike receptor agonists [106•, 118, 123]. Thus, dermal $\gamma \delta \mathrm{T}$ cells are likely to be involved in innate pathogen defense by augmenting neutrophil recruitment via IL-17. Recent studies have also revealed the importance of dermal $\gamma \delta \mathrm{T}$ cells in imiquimod- and IL-23-induced psoriasiform lesions in mice, in which they were the major source of IL-17. Interestingly, it was dermal $\gamma \delta$ T cells, not $\alpha \beta$ T cells or DETCs, that were important for lesion development $[118,121,124 \bullet]$. These findings suggest the intriguing possibility that dermal $\gamma \delta \mathrm{T}$ cells may contribute to the pathology of human psoriasis, given the pivotal roles of IL-17 and IL-23 in this disease [125-127], although this remains speculative.

Human skin also contains a population of dermal $\gamma \delta \mathrm{T}$ cells, most of which express V $\delta 1 \mathrm{TCR}$, contrasting with the $\gamma \delta \mathrm{T}$ cells found in human peripheral blood that comprise largely $\mathrm{V} \delta 2^{+}$cells. Whether this population is the human equivalent to the murine dermal $\gamma \delta \mathrm{T}$ cell remains unclear, although the evidence to date suggests that the two populations do not equate. In contrast to murine $\gamma \delta \mathrm{T}$ cells, which are pre-committed to IL-17 production in the embryonic thymus $[121,128]$, human dermal $\mathrm{V} \delta 1^{+} \mathrm{T}$ cell lines produce TNF $\alpha$ and IFN $\gamma$ when stimulated in culture $[129,130]$. Human blood contains a $\mathrm{V} \gamma 9^{+} \mathrm{V} \delta 2^{+}$subset expressing cutaneous lymphocyte-associated antigen (CLA), the skin-homing receptor. Importantly, these circulating $\mathrm{V} \gamma 9^{+} \mathrm{V} \delta 2^{+}$cells produced IL-17 after bacterial infection and have been identified in psoriatic lesions [131•]. Understanding IL-17-producing innate cells and their functional and survival requirements could lead to targeted therapies, for instance, ROR $\gamma \mathrm{t}$ antagonists.

\section{Innate Lymphoid Cells}

Innate lymphoid cells (ILCs) are a family of newly described cells derived from a common lymphoid progenitor, and are identified by their lack of lineage marker expression (T-cell receptor, B-cell receptor, myeloid and/or DC markers) and their lymphoid morphology [132]. They are further subcategorized according to their developmental requirements and the cytokines that they produce: group 1 ILCs (ILC1) are T-bet dependent and produce IFN $\gamma$; group 2 ILCs (ILC2) are GATA-3 dependent and produce the type 2 cytokines IL-5 and IL-13; and group 3 ILCs (ILC3) are ROR $\gamma$ t-dependent and produce IL-17, IL-22, or both (nomenclature: [133]).

Although originally described in mucosal tissues, significant numbers of ILC2s have been identified in the dermis of both mice and humans $[102 \bullet \bullet, 134 \bullet \cdot]$. Specifically, they were one-third as numerous as $\mathrm{T}$ cells and comprised $5-10 \%$ of $\mathrm{CD} 5^{+}$cells isolated from murine skin. Like other ILCs, dermal ILC2s required IL-7 for their development and survival, and could be replenished by bone marrow-derived cells following irradiation. Dermal ILC2s constitutively produced IL-13, and could upregulate IL-5 and IL-13 production when activated by systemic IL-2 treatment $[102 \bullet \cdot]$, or by topical administration of the vitamin D analogue calcipotriol [134••]. Intravital imaging of dermal ILC2s revealed that these cells scan the dermis but also frequently stop to interact with skinresident mast cells, another effector of type 2 responses $[102 \bullet \bullet]$. Interestingly, ILC2s were enriched in human atopic dermatitis lesions [134••], implicating this population in the pathology of eczema.

Although there is no evidence yet to date that ILC1s or ILC2s reside within normal skin, ILC3s were recruited to 
imiquimod-induced psoriasiform lesions [124•]. Whether equivalent populations of ILC3s are enriched in human psoriasis remains to be determined.

\section{Concluding Remarks}

Research over the past few years has shed new light on the complex functions of skin-resident immune cells in homeostasis and inflammation. The discovery of novel cell populations, such as dermal $\gamma \delta$ T cells and ILC2s, has expanded our knowledge of innate immune sensing and early responses towards pathogens entering the skin. How exactly epidermal and dermal inhabitants interact with each other and the environment and coordinate downstream adaptive immunity is still largely unexplored. The development of transgenic reporter mice with fluorescently tagged immune cell subsets in combination with advanced imaging approaches provides a unique opportunity for furthering our understanding of cutaneous biology in the steady-state and during disease conditions in the years to come.

Acknowledgments P.L.T is supported by a National Health and Medical Research Council Postgraduate Scholarship. W.W. is a fellow of the Cancer Institute New South Wales. This review was supported by grants from the National Health and Medical Research Council and the Australian Research Council.

\section{Compliance with Ethics Guidelines}

Conflict of Interest S.S. Tay declares no conflicts of interest.

B. Roediger declares no conflicts of interest.

P.L. Tong declares no conflicts of interest.

S. Tikoo declares no conflicts of interest.

W. Weninger declares no conflicts of interest.

Human and Animal Rights and Informed Consent This article does not contain any studies with human or animal subjects performed by any of the authors.

Open Access This article is distributed under the terms of the Creative Commons Attribution License which permits any use, distribution, and reproduction in any medium, provided the original author(s) and the source are credited.

\section{References}

Papers of particular interest, published recently, have been highlighted as:

- Of importance

•- Of major importance

1. Urmacher C. Histology of normal skin. Am J Surg Pathol. 1990;14(7):671-86.

2. Murray PJ, Wynn TA. Protective and pathogenic functions of macrophage subsets. Nat Rev Immunol. 2011;11(11):723-37.
3. Dai XM, Ryan GR, Hapel AJ, Dominguez MG, Russell RG, Kapp $\mathrm{S}$, et al. Targeted disruption of the mouse colony-stimulating factor 1 receptor gene results in osteopetrosis, mononuclear phagocyte deficiency, increased primitive progenitor cell frequencies, and reproductive defects. Blood. 2002;99(1):111-20.

4. Yoshida H, Hayashi S, Kunisada T, Ogawa M, Nishikawa S, Okamura $\mathrm{H}$, et al. The murine mutation osteopetrosis is in the coding region of the macrophage colony stimulating factor gene. Nature. 1990;345(6274):442-4.

5. Li J, Chen K, Zhu L, Pollard JW. Conditional deletion of the colony stimulating factor-1 receptor (c-fms proto-oncogene) in mice. Genesis. 2006;44(7):328-35.

6. Pollard JW. Trophic macrophages in development and disease. Nat Rev Immunol. 2009;9(4):259-70.

7. Olefsky JM, Glass CK. Macrophages, inflammation, and insulin resistance. Annu Rev Physiol. 2010;72:219-46.

8. Wynn TA, Chawla A, Pollard JW. Macrophage biology in development, homeostasis and disease. Nature. 2013;496(7446):445-55.

9. Dupasquier M, Stoitzner P, van Oudenaren A, Romani N, Leenen PJ. Macrophages and dendritic cells constitute a major subpopulation of cells in the mouse dermis. J Invest Dermatol. 2004;123(5):876-9.

10. Dupasquier M, Stoitzner P, Wan H, Cerqueira D, van Oudenaren A, Voerman JS, et al. The dermal microenvironment induces the expression of the alternative activation marker CD301/mMGL in mononuclear phagocytes, independent of IL-4/IL-13 signaling. J Leukoc Biol. 2006;80(4):838-49.

11. Goren I, Allmann N, Yogev N, Schurmann C, Linke A, Holdener $\mathrm{M}$, et al. A transgenic mouse model of inducible macrophage depletion: effects of diphtheria toxin-driven lysozyme M-specific cell lineage ablation on wound inflammatory, angiogenic, and contractive processes. Am J Path. 2009;175(1):132-47.

12. Mirza R, DiPietro LA, Koh TJ. Selective and specific macrophage ablation is detrimental to wound healing in mice. Am J Path. 2009;175(6):2454-62.

13. - Lucas T, Waisman A, Ranjan R, Roes J, Krieg T, Muller W, et al. Differential roles of macrophages in diverse phases of skin repair. J Immunol. 2010;184(7):3964-77. By inducing macrophage deletion at sequential times during the wound healing process, this study reveals the different roles of macrophages at the different phases, supporting the concept that they have different functions .

14. Akira S, Takeda K, Kaisho T. Toll-like receptors: critical proteins linking innate and acquired immunity. Nat Immunol. 2001;2(8): 675-80.

15. Mosser DM, Edwards JP. Exploring the full spectrum of macrophage activation. Nat Rev Immunol. 2008;8(12):958-69.

16. Rappolee DA, Mark D, Banda MJ, Werb Z. Wound macrophages express TGF-alpha and other growth factors in vivo: analysis by mRNA phenotyping. Science. 1988;241(4866):708-12.

17. Daley JM, Reichner JS, Mahoney EJ, Manfield L, Henry Jr WL, Mastrofrancesco B, et al. Modulation of macrophage phenotype by soluble product(s) released from neutrophils. J Immunol. 2005;174(4):2265-72.

18. Gordon S, Martinez FO. Alternative activation of macrophages: mechanism and functions. Immunity. 2010;32(5):593-604.

19. Meszaros AJ, Reichner JS, Albina JE. Macrophage phagocytosis of wound neutrophils. J Leukoc Biol. 1999;65(1):35-42.

20. Hume DA. Applications of myeloid-specific promoters in transgenic mice support in vivo imaging and functional genomics but do not support the concept of distinct macrophage and dendritic cell lineages or roles in immunity. J Leukoc Biol. 2011;89(4):525-38.

21. Coombes JL, Robey EA. Dynamic imaging of host-pathogen interactions in vivo. Nat Rev Immunol. 2010;10(5):353-64.

22. van Furth R, Cohn ZA. The origin and kinetics of mononuclear phagocytes. J Exp Med. 1968;128(3):415-35. 
23. Ginhoux F, Greter M, Leboeuf M, Nandi S, See P, Gokhan S, et al. Fate mapping analysis reveals that adult microglia derive from primitive macrophages. Science. 2010;330(20966214):841-5.

24. - Hoeffel G, Wang Y, Greter M, See P, Teo P, Malleret B, et al. Adult Langerhans cells derive predominantly from embryonic fetal liver monocytes with a minor contribution of yolk sac-derived macrophages. J Exp Med. 2012;209(6):1167-81. This study confirmed that Langerhans cells are maintained independently of circulating monocytes and are renewed by precursors that seed the epidermis before birth. Langerhans cells were identified as an ontogenically distinct population amongst myeloid cells, and lineage-tracing studies showed that Langerhans cell precursors are of dual origin, first arising from yolk-sac progenitors but later from fetal-liver monocytes.

25. • Schulz C, Gomez Perdiguero E, Chorro L, Szabo-Rogers H, Cagnard N, Kierdorf K, et al. A lineage of myeloid cells independent of Myb and hematopoietic stem cells. Science. 2012;336(6077):86-90. This study demonstrated that macrophages develop in the embryo before definitive haematopoiesis. These yolk sac-derived macrophages populated several tissues, including the skin, where they gave rise to F4/80bright CX3CRIhi Langerhans cells. This lineage was dependent on the transcription factor PU.1, but not Myb.

26. Hashimoto D, Chow A, Noizat C, Teo P, Beasley MB, Leboeuf M, et al. Tissue-resident macrophages self-maintain locally throughout adult life with minimal contribution from circulating monocytes. Immunity. 2013;38(4):792-804.

27. Jenkins SJ, Ruckerl D, Cook PC, Jones LH, Finkelman FD, van Rooijen N, et al. Local macrophage proliferation, rather than recruitment from the blood, is a signature of $\mathrm{TH} 2$ inflammation. Science. 2011;332(6035):1284-8.

28. Ajami B, Bennett JL, Krieger C, McNagny KM, Rossi FM. Infiltrating monocytes trigger EAE progression, but do not contribute to the resident microglia pool. Nat Neurosci. 2011;14(9):1142-9.

29. Sere K, Baek JH, Ober-Blobaum J, Muller-Newen G, Tacke F, Yokota Y, et al. Two distinct types of Langerhans cells populate the skin during steady state and inflammation. Immunity. 2012;37(5):905-16.

30. Miyake Y, Asano K, Kaise H, Uemura M, Nakayama M, Tanaka M. Critical role of macrophages in the marginal zone in the suppression of immune responses to apoptotic cell-associated antigens. J Clin Invest. 2007;117(8):2268-78.

31. Perry VH, Hume DA, Gordon S. Immunohistochemical localization of macrophages and microglia in the adult and developing mouse brain. Neuroscience. 1985;15(2):313-26.

32. Gautier EL, Shay T, Miller J, Greter M, Jakubzick C, Ivanov S, Helft J, Chow A, Elpek KG, Gordonov S, Mazloom AR, Ma'ayan A, Chua WJ, Hansen TH, Turley SJ, Merad M, Randolph GJ. Immunological Genome Consortium. Gene-expression profiles and transcriptional regulatory pathways that underlie the identity and diversity of mouse tissue macrophages. Nat Immunol. 2012;13(11):1118-28.

33. den Haan JM, Kraal G. Innate immune functions of macrophage subpopulations in the spleen. J Innate Immun. 2012;4(5-6): 437-45.

34. Gordon EJ, Rao S, Pollard JW, Nutt SL, Lang RA, Harvey NL. Macrophages define dermal lymphatic vessel calibre during development by regulating lymphatic endothelial cell proliferation. Development. 2010;137(22):3899-910.

35. Weber-Matthiesen K, Sterry W. Organization of the monocyte/ macrophage system of normal human skin. J Invest Dermatol. 1990;95(1):83-9.

36. Bruns RR, Palade GE. Studies on blood capillaries. II. Transport of ferritin molecules across the wall of muscle capillaries. J Cell Biol. 1968;37(2):277-99.

37. Steinman RM. Dendritic cells: understanding immunogenicity. Eur J Immunol. 2007;37 Suppl 1:S53-60.
38. Ohl L, Mohaupt M, Czeloth N, Hintzen G, Kiafard Z, Zwirner J, et al. CCR7 governs skin dendritic cell migration under inflammatory and steady-state conditions. Immunity. 2004;21(2):279-88.

39. Waithman J, Allan RS, Kosaka H, Azukizawa H, Shortman K, Lutz MB, et al. Skin-derived dendritic cells can mediate deletional tolerance of class I-restricted self-reactive T cells. J of Immunol. 2007;179(7):4535-41.

40. Hemmi H, Yoshino M, Yamazaki H, Naito M, Iyoda T, Omatsu Y, et al. Skin antigens in the steady state are trafficked to regional lymph nodes by transforming growth factor-beta1-dependent cells. Int Immunol. 2001;13(5):695-704.

41. Merad M, Ginhoux F, Collin M. Origin, homeostasis and function of Langerhans cells and other langerin-expressing dendritic cells. Nat Rev Immunol. 2008;8(12):935-47. doi:10.1038/nri2455.

42. Steinman R, Hoffman L, Pope M. Maturation and migration of cutaneous dendritic cells. J Invest Dermatol. 1995;105(1 Suppl):2S-7S

43. Kissenpfennig A, Henri S, Dubois B, Laplace-Builhe C, Perrin P, Romani N, et al. Dynamics and function of Langerhans cells in vivo: dermal dendritic cells colonize lymph node areas distinct from slower migrating Langerhans cells. Immunity. 2005;22(15894281):643-54.

44. Ng LG, Hsu A, Mandell MA, Roediger B, Hoeller C, Mrass P et al. Migratory dermal dendritic cells act as rapid sensors of protozoan parasites. PLoS Pathog. 2008;4(19043558).

45. Nishibu A, Ward BR, Jester JV, Ploegh HL, Boes M, Takashima A. Behavioral responses of epidermal Langerhans cells in situ to local pathological stimuli. J Invest Dermatol. 2006;126(16439974):787-96.

46. Kubo A, Nagao K, Yokouchi M, Sasaki H, Amagai M. External antigen uptake by Langerhans cells with reorganization of epidermal tight junction barriers. J Exp Med. 2009;206(19995951):2937-46.

47. Ouchi T, Kubo A, Yokouchi M, Adachi T, Kobayashi T, Kitashima DY, et al. Langerhans cell antigen capture through tight junctions confers preemptive immunity in experimental staphylococcal scalded skin syndrome. J Exp Med. 2011;208(13):2607-13.

48. Romani N, Clausen BE, Stoitzner P. Langerhans cells and more: langerin-expressing dendritic cell subsets in the skin. Immunol Rev. 2010;234(20193016):120-41.

49. Stoitzner P. The Langerhans cell controversy: are they immunostimulatory or immunoregulatory cells of the skin immune system? Immunol Cell Biol. 2010;88(4):348-50.

50. Ginhoux F, Merad M. Ontogeny and homeostasis of Langerhans cells. Immunol Cell Biol. 2010;88(4):387-92.

51. Ginhoux F, Tacke F, Angeli V, Bogunovic M, Loubeau M, Dai X$\mathrm{M}$, et al. Langerhans cells arise from monocytes in vivo. Nat Immunol. 2006;7(16444257):265-73.

52. Hemmerling J, Wegner-Kops J, von Stebut E, Wolff D, Wagner EM, Hartwig UF, et al. Human epidermal Langerhans cells replenish skin xenografts and are depleted by alloreactive $\mathrm{T}$ cells in vivo. J Immunol. 2011;187(3):1142-9.

53. Kanitakis J, Morelon E, Petruzzo P, Badet L, Dubernard JM. Selfrenewal capacity of human epidermal Langerhans cells: observations made on a composite tissue allograft. Exp Dermatol. 2011;20(2):145-6.

54. - Bigley V, Haniffa M, Doulatov S, Wang XN, Dickinson R, McGovern N, et al. The human syndrome of dendritic cell, monocyte, B and NK lymphoid deficiency. J Exp Med. 2011;208(2):22734. This study investigated four patients diagnosed with a novel immunodeficiency syndrome characterized by a deficit in dendritic cells, monocytes, B cells, and NK lymphoid cells. Dendritic cells in the blood and in the dermis were nearly absent. In contrast, despite pre-existing monocytopenia for more than 10 years, Langerhans cells and dermal macrophages were largely preserved.

55. •- Greter M, Lelios I, Pelczar P, Hoeffel G, Price J, Leboeuf M, et al. Stroma-derived interleukin-34 controls the development and 
maintenance of langerhans cells and the maintenance of microglia. Immunity. 2012;37(6):1050-60. This study demonstrated that in both mice and humans, IL-34 produced by keratinocytes and neurons is required for the development of Langerhans cells and microglia, respectively. IL-34 was also found to be expressed in the dermis, mainly in hair follicles, suggesting they could play a role in Langerhans cell entry into the dermis.

56. •- Wang Y, Szretter KJ, Vermi W, Gilfillan S, Rossini C, Cella M, et al. IL-34 is a tissue-restricted ligand of CSF1R required for the development of Langerhans cells and microglia. Nat Immunol. 2012;13(22729249):753-60. This study found that IL-34 produced by keratinocytes and neurons is an alternative ligand for CSF-1 receptor, and is required for the development of Langerhans cells and microglia, respectively. These findings explained why Langerhans cells and microglia are absent in CSF-1 receptordeficient mice but still present in CSF-1-deficient animals .

57. Borkowski TA, Letterio JJ, Farr AG, Udey MC. A role for endogenous transforming growth factor beta 1 in Langerhans cell biology: the skin of transforming growth factor beta 1 null mice is devoid of epidermal Langerhans cells. J Exp Med. 1996;184(8976197):2417-22.

58. Chorro L, Sarde A, Li M, Woollard KJ, Chambon P, Malissen B, et al. Langerhans cell (LC) proliferation mediates neonatal development, homeostasis, and inflammation-associated expansion of the epidermal LC network. J Exp Med. 2009;206(13):3089-100.

59. Eidsmo L, Allan R, Caminschi I, van Rooijen N, Heath WR, Carbone FR. Differential migration of epidermal and dermal dendritic cells during skin infection. J Immunol. 2009;182(5): 3165-72.

60. Nagao K, Kobayashi T, Moro K, Ohyama M, Adachi T, Kitashima DY, et al. Stress-induced production of chemokines by hair follicles regulates the trafficking of dendritic cells in skin. Nat Immunol. 2012;13(22729248):744-52.

61. Ghigo C, Mondor I, Jorquera A, Nowak J, Wienert S, Zahner SP, et al. Multicolor fate mapping of Langerhans cell homeostasis. J Exp Med. 2013;210(9):1657-64.

62. Valladeau J, Ravel O, Dezutter-Dambuyant C, Moore K, Kleijmeer M, Liu Y, et al. Langerin, a novel C-type lectin specific to Langerhans cells, is an endocytic receptor that induces the formation of Birbeck granules. Immunity. 2000;12(10661407):71-81.

63. Bursch LS, Wang L, Igyarto B, Kissenpfennig A, Malissen B, Kaplan DH, et al. Identification of a novel population of Langerin+ dendritic cells. J Exp Med. 2007;204(13):3147-56.

64. Ginhoux F, Collin MP, Bogunovic M, Abel M, Leboeuf M, Helft $\mathrm{J}$, et al. Blood-derived dermal Langerin+ dendritic cells survey the skin in the steady state. J Exp Med. 2007;204(13):3133-46.

65. Poulin LF, Henri S, de Bovis B, Devilard E, Kissenpfennig A, Malissen B. The dermis contains Langerin+ dendritic cells that develop and function independently of epidermal Langerhans cells. J Exp Med. 2007;204(13):3119-31.

66. Clausen BE, Kel JM. Langerhans cells: critical regulators of skin immunity? Immunol Cell Biol. 2010;88(20351747):351-60.

67. Shklovskaya E, O'Sullivan BJ, Ng LG, Roediger B, Thomas R, Weninger $\mathrm{W}$, et al. Langerhans cells are precommitted to immune tolerance induction. Proc Natl Acad Sci U S A. 2011;108(44): 18049-54.

68. Igyarto BZ, Jenison MC, Dudda JC, Roers A, Muller W, Koni PA, et al. Langerhans cells suppress contact hypersensitivity responses via cognate CD4 interaction and langerhans cell-derived IL-10. J Immunol. 2009;183(8):5085-93.

69. Lutz MB, Dohler A, Azukizawa H. Revisiting the tolerogenicity of epidermal Langerhans cells. Immunol Cell Biol. 2010;88(4): 381-6.

70. Bobr A, Olvera-Gomez I, Igyarto BZ, Haley KM, Hogquist KA, Kaplan DH. Acute ablation of Langerhans cells enhances skin immune responses. J Immunol. 2010;185(8):4724-8.
71. Gomez de Aguero M, Vocanson M, Hacini-Rachinel F, Taillardet M, Sparwasser T, Kissenpfennig A, et al. Langerhans cells protect from allergic contact dermatitis in mice by tolerizing CD8 $(+) \mathrm{T}$ cells and activating Foxp3(+) regulatory T cells. J Clin Invest. 2012;122(22523067):1700-11.

72. Furio L, Briotet I, Journeaux A, Billard H, Peguet-Navarro J. Human langerhans cells are more efficient than CD14(-)CD1c(+ ) dermal dendritic cells at priming naive CD4(+) T cells. J Invest Dermatol. 2010;130(5):1345-54.

73. Mathers AR, Janelsins BM, Rubin JP, Tkacheva OA, Shufesky WJ, Watkins SC, et al. Differential capability of human cutaneous dendritic cell subsets to initiate Th17 responses. J Immunol. 2009;182(2):921-33.

74. Fujita H, Nograles KE, Kikuchi T, Gonzalez J, Carucci JA, Krueger JG. Human Langerhans cells induce distinct IL-22producing CD4+ T cells lacking IL-17 production. Proc Natl Acad Sci U S A. 2009;106(51):21795-800.

75. Klechevsky E, Morita R, Liu M, Cao Y, Coquery S, ThompsonSnipes L, et al. Functional specializations of human epidermal Langerhans cells and CD14+ dermal dendritic cells. Immunity. 2008;29(3):497-510.

76. Henri S, Poulin LF, Tamoutounour S, Ardouin L, Guilliams M, de Bovis B, et al. CD207+ CD103+ dermal dendritic cells crosspresent keratinocyte-derived antigens irrespective of the presence of Langerhans cells. J Exp Med. 2010;207(1):189-206.

77. Shklovskaya E, Roediger B, Fazekas de St Groth B. Epidermal and dermal dendritic cells display differential activation and migratory behavior while sharing the ability to stimulate CD4+ T cell proliferation in vivo. J Immunol. 2008;181(1):418-30.

78. Igyarto BZ, Haley K, Ortner D, Bobr A, Gerami-Nejad M, Edelson BT, et al. Skin-resident murine dendritic cell subsets promote distinct and opposing antigen-specific T helper cell responses. Immunity. 2011;35(2):260-72.

79. Gregorio J, Meller S, Conrad C, Di Nardo A, Homey B, Lauerma A, et al. Plasmacytoid dendritic cells sense skin injury and promote wound healing through type I interferons. J Exp Med. 2010;207(13):2921-30.

80. Bedoui S, Whitney PG, Waithman J, Eidsmo L, Wakim L, Caminschi I, et al. Cross-presentation of viral and self antigens by skin-derived CD103+ dendritic cells. Nat Immunol. 2009;10(5):488-95.

81. Kumamoto Y, Linehan M, Weinstein JS, Laidlaw BJ, Craft JE, Iwasaki A. CD301b Dermal Dendritic Cells Drive T Helper 2 Cell-Mediated Immunity. Immunity. 2013. doi:10.1016/j.immuni. 2013.08.029.

82. Murakami R, Denda-Nagai K, Hashimoto S, Nagai S, Hattori M, Irimura T. A Unique Dermal Dendritic Cell Subset That Skews the Immune Response toward Th2. PLoS One. 2013;8(9):e73270.

83. Haniffa M, Collin M, Ginhoux F. Ontogeny and functional specialization of dendritic cells in human and mouse. Adv Immunol. 2013;120:1-49.

84. •- Haniffa M, Shin A, Bigley V, McGovern N, Teo P, See P, et al. Human tissues contain CD141hi cross-presenting dendritic cells with functional homology to mouse CD103+ nonlymphoid dendritic cells. Immunity. 2012;37(1):60-73. Using previously identified markers that were predicted to be conserved between mouse and human DC subsets, the authors studied DC subsets from various human tissues, including the skin. Using comparative genomics to align human and mouse cells, they found that CD141hiCLEC9A+XCR1+DCs were the human counterpart of mouse CD103+ DCs. Consistent with this, CD141hi DCs were potent at cross-presentation, more so than Langerhans cells.

85. Galli SJ, Tsai M. IgE and mast cells in allergic disease. Nat Med. 2012;18(5):693-704.

86. Galli SJ, Kalesnikoff J, Grimbaldeston MA, Piliponsky AM, Williams CM, Tsai M. Mast cells as "tunable" effector and 
immunoregulatory cells: recent advances. Annu Rev Immunol. 2005;23:749-86.

87. Costanza M, Colombo MP, Pedotti R. Mast cells in the pathogenesis of multiple sclerosis and experimental autoimmune encephalomyelitis. Int J Mol Sci. 2012;13(11):15107-25.

88. Nigrovic PA, Gray DH, Jones T, Hallgren J, Kuo FC, Chaletzky B, et al. Genetic inversion in mast cell-deficient (Wsh) mice interrupts corin and manifests as hematopoietic and cardiac aberrancy. Am J Pathol. 2008;173(6):1693-701.

89. Aoki R, Kawamura T, Goshima F, Ogawa Y, Nakae S, Nakao A, et al. Mast Cells Play a Key Role in Host Defense against Herpes Simplex Virus Infection through TNF-alpha and IL-6 Production. J Invest Dermatol. 2013;133(9):2170-9.

90. Maurer M, Lopez Kostka S, Siebenhaar F, Moelle K, Metz M, Knop J, et al. Skin mast cells control T cell-dependent host defense in Leishmania major infections. Faseb J. 2006;20(14): 2460-7.

91. Siebenhaar F, Syska W, Weller K, Magerl M, Zuberbier T, Metz $\mathrm{M}$, et al. Control of Pseudomonas aeruginosa skin infections in mice is mast cell-dependent. Am J Pathol. 2007;170(6):1910-6.

92. Berrozpe G, Timokhina I, Yukl S, Tajima Y, Ono M, Zelenetz AD, et al. The W(sh), W(57), and Ph Kit expression mutations define tissue-specific control elements located between -23 and $-154 \mathrm{~kb}$ upstream of Kit. Blood. 1999;94(8):2658-66.

93. Grimbaldeston MA, Chen CC, Piliponsky AM, Tsai M, Tam SY, Galli SJ. Mast cell-deficient W-sash c-kit mutant Kit W-sh/W-sh mice as a model for investigating mast cell biology in vivo. Am J Pathol. 2005;167(3):835-48.

94. Nakano T, Sonoda T, Hayashi C, Yamatodani A, Kanayama Y, Yamamura T, et al. Fate of bone marrow-derived cultured mast cells after intracutaneous, intraperitoneal, and intravenous transfer into genetically mast cell-deficient $\mathrm{W} / \mathrm{Wv}$ mice. Evidence that cultured mast cells can give rise to both connective tissue type and mucosal mast cells. J Exp Med. 1985;162(3):1025-43.

95. Dudeck A, Dudeck J, Scholten J, Petzold A, Surianarayanan S, Kohler A, et al. Mast cells are key promoters of contact allergy that mediate the adjuvant effects of haptens. Immunity. 2011;34(6): 973-84.

96. - Lilla JN, Chen CC, Mukai K, BenBarak MJ, Franco CB, Kalesnikoff $\mathrm{J}$, et al. Reduced mast cell and basophil numbers and function in Cpa3-Cre; Mcl-1fl/fl mice. Blood. 2011;118(26): 6930-8. Describes the generation of mice with Kit-independent mast cell deficiency, an important advance for studying mast cell function in vivo. These "Hello Kitty" mice were generated by crossing mice expressing Cre recombinase from the mast cell carboypeptidase A promoter (Cpa3-Cre) to mice, in which the first exon of the anti-apoptotic factor Mcl-1 is flanked by loxP sites. (Mcl-1fl). The progeny are deficient in mast cells and basophils, and IgE-dependent inflammation was found to be reduced in these animals.

97. Feyerabend TB, Weiser A, Tietz A, Stassen M, Harris N, Kopf M, et al. Cre-mediated cell ablation contests mast cell contribution in models of antibody- and T cell-mediated autoimmunity. Immunity. 2011;35(5):832-44.

98. - Ando T, Matsumoto K, Namiranian S, Yamashita H, Glatthorn $\mathrm{H}$, Kimura M et al. Mast Cells Are Required for Full Expression of Allergen/SEB-Induced Skin Inflammation. J Invest Dermatol. 2013. This study implicated mast cells (and Tcells) in a murine model of atopic dermatitis that closely mimics human eczematous skin. Pathology is induced by repeated epicutaneous application of house dust mite extract and Staphylococcal enterotoxin B. The role of mast cells was tested in both Kit-dependent and Kitindependent mast cell-deficient strains of mice.

99. Belloni B, Andres C, Ollert M, Ring J, Mempel M. Novel immunological approaches in the treatment of atopic eczema. Curr Opin Allergy Clin Immunol. 2008;8(5):423-7.
100. Liu FT, Goodarzi H, Chen HY. IgE, mast cells, and eosinophils in atopic dermatitis. Clin Rev Allergy Immunol. 2011;41(3): 298-310.

101. Cheng LE, Hartmann K, Roers A, Krummel MF, Locksley RM. Perivascular mast cells dynamically probe cutaneous blood vessels to capture immunoglobulin E. Immunity. 2013;38(1):166-75.

102. •• Roediger B, Kyle R, Yip KH, Sumaria N, Guy TV, Kim BS, et al. Cutaneous immunosurveillance and regulation of inflammation by group 2 innate lymphoid cells. Nat Immunol. 2013;14(23603794):564-73. This study identified and visualized skin-resident ILC2 cells in the mouse dermis, and showed that these cells can be activated in vivo by IL-2 administration, which led to skin inflammation.

103. Macleod AS, Havran WL. Functions of skin-resident gammadelta T cells. Cell Mol Life Sci. 2011;68(14):2399-408.

104. Heilig JS, Tonegawa S. Diversity of murine gamma genes and expression in fetal and adult $\mathrm{T}$ lymphocytes. Nature. 1986;322(2943999):836-40.

105. Uchida Y, Kawai K, Ibusuki A, Kanekura T. Role for E-cadherin as an inhibitory receptor on epidermal gammadelta $\mathrm{T}$ cells. $\mathrm{J}$ Immunol. 2011;186(21562159):6945-54.

106. - Sumaria N, Roediger B, Ng LG, Qin J, Pinto R, Cavanagh LL, et al. Cutaneous immunosurveillance by self-renewing dermal gammadelta T cells. J Exp Med. 2011;208(21339323):505-18. The first characterization of dermal gamma delta T cells in mice. The authors demonstrated that IL-17 production by these cells augmented neutrophil influx into the skin following infection with mycobacteria.

107. Chodaczek G, Papanna V, Zal MA, Zal T. Body-barrier surveillance by epidermal gammadelta TCRs. Nat Immunol. 2012;13(3): 272-82.

108. Moore TA, von Freeden-Jeffry U, Murray R, Zlotnik A. Inhibition of gamma delta $\mathrm{T}$ cell development and early thymocyte maturation in IL- ${ }^{-/-}$mice. J Immunol. 1996;157(6):2366-73.

109. Laky K, Lefrancois L, von Freeden-Jeffry U, Murray R, Puddington L. The role of IL-7 in thymic and extrathymic development of TCR gamma delta cells. J Immunol. 1998;161(2):707-13.

110. De Creus A, Van Beneden K, Stevenaert F, Debacker V, Plum J, Leclercq G. Developmental and functional defects of thymic and epidermal V gamma 3 cells in IL-15deficient and IFN regulatory factor-1-deficient mice. J Immunol. 2002;168(12):6486-93.

111. Boismenu R, Havran WL. Modulation of epithelial cell growth by intraepithelial gamma delta T cells. Science. 1994;266(7973709): 1253-5.

112. Jameson J, Ugarte K, Chen N, Yachi P, Fuchs E, Boismenu R, et al. A role for skin gammadelta $\mathrm{T}$ cells in wound repair. Science. 2002;296(11976459):747-9.

113. Macleod AS, Hemmers S, Garijo O, Chabod M, Mowen K, Witherden DA, et al. Dendritic epidermal T cells regulate skin antimicrobial barrier function. J Clin Invest. 2013. doi:10.1172/ JCI70064.

114. Sharp LL, Jameson JM, Cauvi G, Havran WL. Dendritic epidermal $\mathrm{T}$ cells regulate skin homeostasis through local production of insulin-like growth factor 1. Nat Immunol. 2005;6(15592472):73-9.

115. Cho JS, Pietras EM, Garcia NC, Ramos RI, Farzam DM, Monroe HR, et al. IL-17 is essential for host defense against cutaneous Staphylococcus aureus infection in mice. J Clin Invest. 2010;120(5):1762-73.

116. Tamaki K, Yasaka N, Chang CH, Ohtake N, Saitoh A, Nakamura $\mathrm{K}$, et al. Identification and characterization of novel dermal Thy-1 antigen-bearing dendritic cells in murine skin. J Invest Dermatol. 1996;106(8648196):571-5.

117. Kisielow J, Kopf M, Karjalainen K. SCART scavenger receptors identify a novel subset of adult gammadelta T cells. J Immunol. 2008;181(3):1710-6. 
118. Cai Y, Shen X, Ding C, Qi C, Li K, Li X, et al. Pivotal role of dermal IL-17-producing gammadelta T cells in skin inflammation. Immunity. 2011;35(21982596):596-610.

119. Gray EE, Suzuki K, Cyster JG. Cutting edge: Identification of a motile IL-17-producing gammadelta $\mathrm{T}$ cell population in the dermis. J Immunol. 2011;186(21536803):6091-5.

120. Mrass $\mathrm{P}$, Takano $\mathrm{H}, \mathrm{Ng}$ LG, Daxini S, Lasaro MO, Iparraguirre $\mathrm{A}$, et al. Random migration precedes stable target cell interactions of tumor-infiltrating $\mathrm{T}$ cells. J Exp Med. 2006;203(17116735):2749-61.

121. Gray EE, Ramirez-Valle F, Xu Y, Wu S, Wu Z, Karjalainen KE, et al. Deficiency in IL-17-committed Vgamma4+ gammadelta T cells in a spontaneous Sox13-mutant CD45.1(+) congenic mouse substrain provides protection from dermatitis. Nat Immunol. 2013;14(23624556):584-92.

122. Martin B, Hirota K, Cua DJ, Stockinger B, Veldhoen M. Interleukin-17-producing gammadelta $\mathrm{T}$ cells selectively expand in response to pathogen products and environmental signals. Immunity. 2009;31(2):321-30.

123. Sutton CE, Lalor SJ, Sweeney CM, Brereton CF, Lavelle EC, Mills KH. Interleukin-1 and IL-23 induce innate IL-17 production from gammadelta T cells, amplifying Th17 responses and autoimmunity. Immunity. 2009;31(2):331-41.

124. • Pantelyushin S, Haak S, Ingold B, Kulig P, Heppner FL, Navarini $\mathrm{AA}$, et al. Rorgammat+ innate lymphocytes and gammadelta $\mathrm{T}$ cells initiate psoriasiform plaque formation in mice. J Clin Invest. 2012;122(22546855):2252-6. This study showed that, in addition to dermal gamma-delta Tcells, there is an innate lymphoid population that may be recruited to the dermis that produces $I L-17$ and IL-22, now classified as Group 3 ILCs. These cells have a role in imiquimod-induced psoriasiform lesions in mice.

125. Di Cesare A, Di Meglio P, Nestle FO. The IL-23/Th17 axis in the immunopathogenesis of psoriasis. J Invest Dermatol. 2009;129(19322214):1339-50.

126. Martin DA, Towne JE, Kricorian G, Klekotka P, Gudjonsson JE, Krueger JG, et al. The emerging role of IL-17 in the pathogenesis of psoriasis: preclinical and clinical findings. J Invest Dermatol. 2013; 133(1):17-26.

127. Tonel G, Conrad C, Laggner U, Di Meglio P, Grys K, McClanahan TK, et al. Cutting edge: A critical functional role for IL-23 in psoriasis. J Immunol. 2010;185(10):5688-91.

128. Ribot JC, DeBarros A, Pang DJ, Neves JF, Peperzak V, Roberts SJ, et al. CD27 is a thymic determinant of the balance between interferon-gamma- and interleukin 17producing gammadelta $\mathrm{T}$ cell subsets. Nat Immunol. 2009;10(19270712):427-36.

129. Bos JD, Teunissen MB, Cairo I, Krieg SR, Kapsenberg ML, Das $\mathrm{PK}$, et al. T-cell receptor gamma delta bearing cells in normal human skin. J Invest Dermatol. 1990;94(1):37-42.

130. Ebert LM, Meuter S, Moser B. Homing and function of human skin gammadelta $\mathrm{T}$ cells and NK cells: relevance for tumor surveillance. J Immunol. 2006;176(7):4331-6.

131. - Laggner U, Di Meglio P, Perera GK, Hundhausen C, Lacy KE, Ali N, et al. Identification of a novel proinflammatory human skinhoming Vgamma9Vdelta2 $\mathrm{T}$ cell subset with a potential role in psoriasis. J Immunol. 2011;187(5):2783-93. This study showed that there is a population of skin-homing Vgamma9Vdelta2 Tcell subset in human blood that can be recruited into inflamed psoriatic skin, where they were shown to produce IL-17, amongst other cytokines.

132. Spits H, Cupedo T. Innate lymphoid cells: emerging insights in development, lineage relationships, and function. Annu Rev Immunol. 2012;30(22224763):647-75.

133. Spits H, Artis D, Colonna M, Diefenbach A, Di Santo JP, Eberl G, et al. Innate lymphoid cells-a proposal for uniform nomenclature. Nat Rev Immunol. 2013;13(23348417):145-9.

134. •- Kim BS, Siracusa MC, Saenz SA, Noti M, Monticelli LA, Sonnenberg GF, et al. TSLP elicits IL-33-independent innate lymphoid cell responses to promote skin inflammation. Sci Transl Med. 2013;5(23363980):170. This study identified ILC2s in normal human and mouse skin and showed that their numbers were elevated human atopic skin lesions. 